\title{
Eritrean Education System: A critical Analysis and Future Research Directions
}

\author{
Tedros Sium Mengesha ${ }^{1} \&$ Mussie T. Tessema, ${ }^{2, *}$ \\ ${ }^{1}$ Comparative Education Research Center, University of Hong Kong Room 401D, Runme \\ Shaw Building, Pokfulam Rd, Hong Kong SAR \\ ${ }^{2}$ Business Administration Dept., College of Business, Winona State University, Som302, \\ Winona, MN, 55987, USA \\ *Corresponding author: Business Administration Dept., College of Business, Winona State \\ University, Som302, Winona, MN, 55987, USA. Tel: 1-507-457-2571. E-mail: \\ Mtessema@winona.edu
}

Received: November 5, 2018 Accepted: December 24, 2018 Published: March 7, 2019

doi:10.5296/ije.v11i1.14471ＵRL: https://doi.org/10.5296/ije.v11i1.14471

\begin{abstract}
This paper critically discusses the Eritrean education system at different period of time: before the Italian colonization (before 1889), Italian colonialization (1889-1941), British Administration (1941-1952), Federation with Ethiopia (1952-1962), annexation of Eritrea by Ethiopia (1962-1961), after independence (after 1991). An important finding of the current study is that, education system is significantly influenced by the economic and political situation of a country in that when the economic and political situation of a country is not conducive, the education system suffers. This study also discusses the implications of the findings of the current study and future research directions.
\end{abstract}

Keywords: Education system, Economic and political situation, Challenges, Eritrea 


\section{Introduction}

A growing body of scholarly studies and reports of prominent international organizations have shown that education is a powerful instrument that paves ways for political, social, and economic advancements and prosperity of nations and societies (Collins \& Wiseman, 2012; Dutta \& Choudhury, 2015; UNESCO, 2015). According to the insights from UNESCO, education empowers and impacts on the well-being of societies and the prosperity of nations in a number of ways. It significantly contributes to the betterment of people's lives by way of bringing radical changes in poverty and hunger, gender equality, child mortality, maternal health, HIV and AIDS, environmental sustainability and global development (UNESCO, 2011). As argued by Stacey (1998), the impacts of education are not only associated with earnings or economic benefits for individuals but also with a wide range of social benefits such as better health, well-being of women, effects on fertility, and creating safe environments. Thus, education matters in the world today because it has substantial impacts in terms of liberating people from illiteracy, diseases, hunger, and poverty. This being the fact, the Eritrean education system has had many challenges (MoE, 2011; Rena, 2005). Although many studies have been conducted on Eritrean education system, there is a scarcity on systematic analysis of the Eritrean education system at different period of time and the challenges which have been facing it. This study therefore attempts to fill the gap.

This study is presented as follows. First, it provides the demographics of Eritrea. Second, it provides the overview of the Eritrean economy. Third, it discusses the Eritrean education system at different period of time. Finally, it forwards the study's conclusions and future research directions.

\section{Demographics of Eritrea}

Eritrea is a young country, having become a sovereign state in 1991 after 30 years of fighting for independence against Ethiopian regimes. It is located in the Horn of Africa bordered by Sudan to the north and west, Ethiopia to the south, Djibouti to the south-east and the Red Sea to the north and north-east. It also shares maritime borders with Saudi Arabia and Yemen. The country covers a land area of about $125.000 \mathrm{~km}^{2}$, stretching from 18.22 ' to 12.42 ' degrees longitude. It possesses a coastline which stretches over 1,200 km. along the Red Sea constituting about 390 islands, including the Dahlak Archipelago (Ministry of Land, Water \& Environment, MLWE, 2001, p. 12). Eritrea's location puts the country in a strategic position of international shipping routes that connects the Mediterranean Sea with the Indian Ocean. The region has long been known a site of instability and subsequent political problems characterized by a series of wars, disputes, and political interest of superpowers (Al-Anazi, 2001; Schraeder, 1992; Schwab, 1978). It has also been plagued by frequent and protracted drought, famine, and extreme poverty (Hutchison, Spooner, \& Walsh, 1991; White, 2005).

Eritrea is a heterogeneous society which consists of nine ethno-linguistic groups and roughly half Christians and half Muslims who lived in harmony and unity for many years. Eritrean nationalism is a strong and unique identity that evolved during the armed struggle for 
independence and held people from all walks of life in the country together for a common purpose (Pool, 1997; Tronvoll, 1998; Welde Giorgis, 2010). Administratively, the country is divided into six regions (known as Zobas) which include Anseba, Debub, Gash-Barka, Maekel, Northern Red Sea, and Southern Red Sea. Each region is subdivided into districts or sub-regions which are further divided into administrative areas. Accordingly, there are 58 sub-regions, 704 administrative areas and about 2,580 villages in Eritrea (Ministry of Education, MoE, 2013, p. 1). Apart from very few household surveys, no proper population census has been conducted in Eritrea since independence (MoE, 2013). Therefore, various sources have been using different figures for Eritrea's population size. For example, while the Eritrean population was 6.3 million according to the UNDP (UNDP, 2013), it was 6.1 million according to the World Bank (World Bank, 2014). The annual growth rate of the Eritrean population was estimated at 3.7 percent (WHO, 2010). While the rural population is about 80 percent, the urban population is about 20 percent (UNDP, 2013).

\section{Overview of the Eritrean Economy}

Eritrea is one of the poorest countries in Sub-Saharan Africa (World Bank, 2014) which is categorized along the 26 low income nations in Africa (World Bank, 2013, p. 5). About two-thirds of Eritrea's population is said to be "poor" (Bahta \& Haile, 2013, p. 73). At a national level, from 2000 to 2006 , the percentage of population below the poverty line was estimated about 53 percent (UNECA, 2012, p. 11) and in 2007 it was about 66 percent (MLWE, 2007, p. 2). Table 1 provides further information on the economic situation in Eritrea.

Table 1. Eritrea's Annual GDP Forecasts for the 2012 to 2014

\begin{tabular}{llll}
\hline Annual GDP forecasts - Eritrea & $\mathbf{2 0 1 2}$ & $\mathbf{2 0 1 3}$ & $\mathbf{2 0 1 4}$ \\
\hline Government of the State Eritrea (GSE) & $7-10 \%$ & $7-10 \%$ & $7-10 \%$ \\
Economist Intelligence Unit (EIU) & $4.5 \%$ & $7.0 \%$ & $8.0 \%$ \\
African Development Bank (ADB) & $5.5 \%$ & $7.0 \%$ & $6.5 \%$ \\
The International Monetary Fund (IMF) & $7.5 \%$ & $1.1 \%$ & $1.9 \%$ \\
\hline
\end{tabular}

Source: Madote.com (2013)

According to the 2017 Human Development Index, Eritrea ranked 179 out of 185 countries and territories, which placed it even the lowest among the countries in the Horn of Africa (UNDP, 2017). Table 2 also provides some information on the general state of Eritrea's socio-economic conditions. 
Table 2. Basic Country Data 2019, Vol. 11, No. 1

\begin{tabular}{|c|c|c|}
\hline Indicator & Remarks & Sources \\
\hline Ethnic groups & $\begin{array}{l}\text { Afar } 5 \% \text {, Bilen } 2 \% \text {, Hidareb } 2.5 \% \text {, Kunama } 2 \% \text {, Nara } 1.5 \% \text {, } \\
\text { Rashaida } 2.4 \% \text {, Saho } 5 \% \text {, Tigre } 31 \% \text {, \& Tigrinya } 50 \%\end{array}$ & Woldemikael, 2003 \\
\hline Life expectancy at birth - total population & Male 63 years, female 67 years & (WHO, 2016) \\
\hline Adult literacy ( $\%$ of population age $15+)$ & Male $79 \%$; female $58 \%$ & ICPD, 2012 \\
\hline Education for all Development Index & 0.634 & UNESCO, 2011 \\
\hline Number of schools & Elementary 875 , middle $315, \&$ secondary 92 & MoE, 2012 \\
\hline Enrollment in elementary school education & Nationwide gross enrollment 334, 245 students & MoE, 2012 \\
\hline \multirow{3}{*}{ School enrolment, primary school education } & Female enrollment: $44.8 \%$ & \\
\hline & Net enrollment: male $37 \%$ \& female $33 \%$ & ICPD, 2012 \\
\hline & Gross $46 \%$ \& net $33 \%$ & World Bank, 2014 \\
\hline Enrollment in middle school education & Gross enrollment: $167,928 \&$ female enrollment $44.5 \%$ & MoE, 2012 \\
\hline School completion rate & Primary $31 \%$ \& middle, $29.2 \%$ & World Bank, 2014 \\
\hline Female school completion rate & Primary $28 \% \&$ middle $28.9 \%$ & World Bank, 2014 \\
\hline Children out of school, primary & 517,937 & World Bank, 2014 \\
\hline Drop-out rate to the last grade of middle school & Cumulative drop-out rate $13.6 \%$ & World Bank, 2014 \\
\hline Repetition rate in middle school education & Both sexes $14.8 \%$ \& of female $11.8 \%$ & MoE, 2012 \\
\hline Survival rate to last grade, primary \& middle school & Primary $73 \%$ \& lower secondary $86.3 \%$ & World Bank, 2014 \\
\hline Progression rate from middle to secondary & $90 \%$ & World Bank, 2014 \\
\hline Public expenditure on education \% of GDP (2006) & $2.1 \%$ & ICPD, 2012 \\
\hline GDP (US \$ billions) (2012) & 3.1 & World Bank, 2014 \\
\hline GDP growth (2012) & $7.0 \%$ & World Bank, 2014 \\
\hline GDP per capita growth (2012) & $3.6 \%$ & World Bank, 2014 \\
\hline Average annual per capita income (2012) & $\$ 450$ & World Bank, 2014 \\
\hline
\end{tabular}

The country is endowed with various types of resources such as gold, copper, potash, silver, marble, oil and natural gas (MLWE, 2001, p. 18). The gold mining, which began in 2011, is viewed by the national government and other international observers as the country's chief international resource which is expected to contribute significantly to Eritrea's economy (The Japan Times, 2009). Eritrea's industries are mainly small to medium scale manufacturing enterprises that consist of food processing, beverages, tobacco, clothing and textiles, light manufacturing, wood, printing, salt, and cement (MLWE, 2001; The Japan Times, 2009). According to AfDB, Eritrea showed a decline in real GDP growth from 3.8 percent in 2016, to 3.4 percent, in 2017 (AfDB, 2018). The data also indicated that agriculture made 17.2 percent of the country's GDP.

The country was able to make significant and sustained strides in rehabilitating the socio-economic well-being of the society, especially from 1993 up to 1997 when the Eritrean economy grew by an average of 11 percent per year (IFAD, 2009; World Bank, 2014). This was hampered, however, by the 1998 border war that broke out between Eritrea and Ethiopia. The border war was officially brought to an end with the signing of cease-fire in 2000. Since then the condition in Eritrea has been described as 'no-war no-peace situation'. Such a 
situation has contributed significantly in worsening the socio-economic conditions in the country which was witnessed by the dramatic escalations in the rate of inflation (IFAD, 2009) and low economic growth. Furthermore, under the 'no-war no-peace' situation, the majority of the productive workforce in the country, including teachers, have been engaged in extended national service duties. On July 9, 2018, however, Eritrean and Ethiopia signed a joint declaration formally ending the border conflict (the 1998-2000 border war and of the 2000-2018 'no-war no-peace situation'). It is hoped that the signed agreement could have a positive impact on Eritrean economy (CBS News, 2018).

\section{Overview of Eritrean Education System}

\subsection{A Brief History of the Eritrean Education System}

\subsubsection{Before Italian Colony (1889)}

Before the Italian colony, Eritrean customary education was provided by priests and sheikhs. It was aimed at preserving spiritual, moral and cultural norms and values as well as traditional gender roles (MOE, 2009). Education was given at churches, monasteries and mosques. During this time, boys and girls were apprenticed in a way that prepared them to follow the paths of their parents and religions so that they could be "good" wives and mothers or "good" husbands and fathers and also loyal to their respective faiths and religions. In the 19th century, the expatriate missionaries who pioneered modern education in Eritrea introduced subjects such as history, geography and crafts, albeit their primary agenda had been to disseminate their own religious faith and doctrines (MOE, 2009, p. 3). The first modern school was opened in Eritrea by Swedish Evangelical missionaries in the port city of Massawa in 1860s (Gottesman, 2002, p. 412). The subjects introduced by the Swedish missionaries emphasized vocational skills such as woodwork, and metalwork and the teaching the local languages of Tigre, Tigrinya, and Kunama. Later on, the Ottomans opened the first Islamic school in 1870s in Massawa as well (Kidane, 2004, p. 12).

\subsubsection{Italian Colonization (1889-1941)}

When the Italians, as the colonial power (1889-1941), stepped their feet in Eritrea, they exerted pressure on the mission schools to close down and established their own schools. For quite some time, the curriculum used was Italian, the language of instruction was Italian, and the students were also only Italians. Gradually, the Italians began to expand the provision of education to Eritreans but also to inculcate the doctrine of their colonial education policy. By 1909 separate schools for Italians and Eritreans were enforced and the provision of education to Eritreans was restricted only up to Grade Four (Gottesman, 2002). From all accounts, racist policy was applicable even in terms of residential segregation, and required Eritreans to use separate public transport, restaurants, bars, and legal system (Weldeyesus, 2009, p. 3). As reported by Gottesman (2002), by the end of 1920s the provision of education was expanded to eight centers that accommodated nearly 1000 students across the country. As stated in State University.com (2014, p. 10), in 1938/39 academic year, the number of schools increased to about twenty schools serving 4,177 students. Generally, however, access to 
educational opportunities for Eritreans under the Italian colonization was only possible after World War I (Kidane, 2004). Besides, educational opportunities were limited to locals who were meant to serve the Italians as translators, office secretaries, and other public servants (Weldeyesus, 2009).

\subsubsection{British Administration (1941-1952)}

During the British administration (1941-1952), Eritreans were allowed to attend schooling beyond elementary level (Gottesman, 2002). Reading, writing, and hygiene, were offered as common subjects to both boys and girls. The curriculum offered for boys, however, was focused on "... agriculture, woodworking, clay-modeling, carpet-making, and shoe-making" and that for girls on "...weaving, sewing, basket work, and domestic science" (StateUniversity.com, 2014, p. 11). At the very beginning of their colonial rule, the British appeared to adopt different developmental strategies than those used by the Italians. They took some measures aimed at banning the Italian discrimination policy in education, allowing Eritreans to use textbooks written in Tigrigna and Arabic, and establishing a local teacher training college. As a result, towards the end of the British administration, there were 100 primary, 14 junior and 2 secondary schools serving 13,500, 1,200 and 67 students respectively (Tesfagiorgis, 2010, p. 59). Be that as it may, the British did not bring economic and political liberation to the rural population. Instead they eventually retained most of the Italian discriminative policies by empowering the administrative and economic positions of the remnants of the Italian administration system (Tesfagiorgis, 2010; Weldeyesus, 2009). The criteria to join middle school level required Eritreans to have developed fair or good communication skills in English (Gottesman, 2002). This had the effect of excluding all apart from people who lived in Asmara and other major towns who were most probably nominees to serve the system. Almost all the schools were built in urban areas, and mainly in Asmara.

\subsubsection{Federation of Eritrea with Ethiopia}

When the United Nations General Assembly decided to federate Eritrea with Ethiopia (1952-1962), Eritreans were able to build for the first time in their history an education system that responded to the needs and aspirations of their identity. That historical momentum resulted in the use of Arabic and Tigrigna languages as medium of instruction in elementary schools and the emergence of Eritrean schools and Eritrean teachers (MOE, 2009).

\subsubsection{Annexation of Eritrea by Ethiopia}

In 1962, Eritrea was annexed to Ethiopia, and was declared as Ethiopia's 14th province. Thus, towards the end of 1960s, those developments were curtailed and resulted in the hegemony of Amharic (Ethiopian language) textbooks and Ethiopian teachers who were actually paid 30 percent higher than their Eritrean counterparts (Gottesman, 2002, p. 412). Eventually those coercive practices led to the use of Amharic language as the medium of instruction in elementary schools and the teaching of that language as a compulsory subject at all levels. Soon after, all educational decisions started to stem from Addis Ababa, the capital of Ethiopia. During the Dergue (1974-1991), a regime that replaced the government of Emperor Haile 
Selassie I (and changed its name later to the People's Democratic Republic of Ethiopia), policies remained the same. During this era, mass arrest, torture and killings of teachers and other educated Eritreans and discrimination against Eritreans on professional development opportunities were common phenomena (StateUniversity.com, 2014, para 19). On the eve of independence, almost about 84 percent of the schools in Eritrea were in a dilapidated condition characterized by total destruction of infrastructure and resources (Hailemariam, 2000; Rena, 2005). The education systems introduced by the successive colonial administrations reflected the objectives and priorities of the particular groups and authorities who appeared on the scene.

\subsubsection{After Eritrean Independence (1991)}

The current education system in Eritrea emphasizes the role of education in nation building and is linked to the policies, visions and practices such as the principles of social justice, self-reliance, and other values that were cultivated during the war for independence $(\mathrm{MoE}$, 2011). The Revolution School (also known as Zero School), which was founded by the Eritrean People's Liberation Front (EPLF) in 1976, had considerable repute as a laboratory of Eritrean curricula, and its chief pedagogical principle was the integration of theory and practice (MOE, 2009; Pateman, 1998). The boarding school was attended by children of the freedom fighters, orphans, nomads, children of families who fled from the then enemy lines, and a sizable number of teenagers who wanted to be freedom fighters but were not old enough to go to the front lines (Bjorndal, n.d.; Gottesman, 1998; Pateman, 1998).

Unlike other liberation movements in Africa, the EPLF was able to establish schools, hospitals, and other public services. The EPLF was operating almost as a functioning government amidst the gunfire (Gottesman, 2002; Iyob, 1997; Welde Giorgis, 2010). During the war for liberation, the EPLF conceived education and health care as the primary rights of the masses (Johnson \& Johnson, 1981). "Illiteracy is our main enemy" was among the most famous slogans used by the EPLF during the war (Gottesman 20012; Sorenson, 1988). Inspired by such an ideology, the liberation front viewed education as an integral part of the struggle for independence and made it compulsory for every member of its organization to attend literacy courses (Campbell, 2005; Iyob, 1997; Stefanos, 1997; Sorenson, 1988). It also provided formal education to thousands of children from all ethnic groups and sectors of the society through their mother tongue language in the then liberated and semi liberated areas (MOE, 2011; MOE, 2013). Furthermore, from 1983 to 1987, the organization launched a national adult literacy campaign behind the enemy lines not only to teach the masses basic literacy skills (reading, writing, and numeracy) but also to transform the lifestyle of the rural communities (Gottesman, 1998). The young teachers who were themselves the product of the EPLF's Zero School, had sought to battle illiteracy as well as equip the rural communities with skills and knowledge related to hygiene, health and sanitation, maternal health, fundamentals of entrepreneurship and improved agricultural practices. The campaign was in particular beneficial to women, who were 60 percent of the participants (Gottesman, 2002, p. 413). This was because it played a significant role in bringing some fundamental changes to their understandings about the hindrance of ignorance, superstitions, stereotypes, and other harmful beliefs (Sorenson, 1988). The literacy campaign which reached 56,000 adults 
(Gottesman, 2002, p. 413) and was also used as a necessary means of mobilizing and raising the political consciousness of the rural masses about the Eritrean war for independence (Bjorndal, n.d.).

After independence, education continued to be claimed by the Eritrean government as a top priority and a cornerstone for all development strategies (GSE, 1994; GSE, 2004; MOE, 2001). Investment in education has been increasing significantly throughout the independence period which varied between 8 to 10 percent of the national budget (MOE, 2013, p. 5). The objectives, and principles stated in most policy documents envisaged the significant role of the education sector in the reconstruction, rehabilitation, and development of the new Eritrea and in particular its contribution to addressing poverty and other aspects of social inequalities (GSE, 2004; MOE, 2013).

The key policy objectives of the Eritrean Ministry of Education include universal primary education up to grade eight, elimination of gender disparities at all levels, the use of mother tongue as a medium of instruction at basic education and English from junior-level onwards, equity and inclusion in education, and life-long education (MOE, 2003; MOE, 2011). In an attempt to implement its intentions and visions, in March 2005, the Ministry of Education established an Education Sector Development Program (ESDP). Among several objectives, the ESDB aspired to raise the participation of school-age children at middle school level from 10.5 percent in 2004/5 academic year to 20 percent by 2015 (AfDB, 2004). Similarly, the project intended to decrease the repetition and dropout rates at middle school level from 23 percent and 10 percent in 2004/5 to 10 percent and 5 percent in 2015 respectively. Despite some notable improvements, a number of the aims that were stated in that project were not met.

\subsection{The Structure and Management of the Current Education System}

\subsubsection{Management Systems, Structures and Issues at Macro-level}

Among the 18 ministries of the country, the Ministry of Education is one of Eritrea's largest government entities which is responsible for planning, managing, monitoring, and overseeing the overall educational programs in the country. The training of teachers, designing of curriculum, setting standards, preparing textbooks, and the supervision of teaching - learning process in schools come under the jurisdiction of the Ministry of Education (MoE, 2013). At the national level, the organizational structure is comprised of five departments which are headed by directors-general and other seven divisions and offices that fall under the auspices of the Minister. The directors-general who are appointed by the President of the State are entrusted with the task of policy-level planning, managing and monitoring of sub-sector programs. The departments constitute Administration and Finance, Adult and Media Education, General Education, Research and Human Resources Development, and Technical Education and Vocational Training. Each department consists of three divisions which are headed by directors who are designated by the Minster of Education. Since independence there have been several changes in the organizational structure of the Ministry of Education in Eritrea. The education system in Eritrea is largely a public service but there are also some private education providers in the country that range from pre-school up to the secondary 
education level (MOE, 2013). Private and semi-private schools are mainly prevalent in major cities and are very few in number.

The Eritrean education system is secular (MOE, 2011) and religious affiliated schools are prohibited from promoting religious beliefs in schools. As stated in the education policy, education is free by law at all levels of the system. This refers to school fees/tuition including at higher education level. For higher education, students are not only exempted from paying tuition fees, but also are provided with free accommodation and daily meals. Yet, at all levels, the families have to shoulder educational expenses, such as for learning materials, uniforms, transportation, and various administrative costs that are imposed by schools. Such expenses are often burdensome for families in the rural areas and among poor households.

The academic year begins in September and ends in late June at all levels of the school system and in every region. By law, the academic calendar in Eritrea consists of 180 teaching days and two semesters in a year, and eighteen weeks in each semester (MOE, 2009, p. 41). Due to the variations in weather conditions, schools in highland areas operate five days a week, and schools in lowland areas function six days a week. In accordance with the schedule stipulated in the National Curriculum framework, the weekly period allocation varies between 30 and 35 at the different levels and are implemented on the basis of six or seven periods per day. Each lesson lasts from 40 up to 45 minutes. On the ground, especially in remote geographical locations, a considerable amount of time is wasted each year due to various reasons. Eritrea has suffered from an acute shortage of supervisors and teachers, in terms of both quantity and quality. Though the growth of number of female teachers was encouraging during the first few years of independence, the lack of teachers also denotes to the declining number of female teachers at all levels. Currently the percentages of female teachers at elementary, middle and secondary levels are only 40.6 percent, 14.4 percent and 14.4 percent of the total teachers respectively (MOE, 2013, p. 24). The shortage of qualified supervisors and teachers together with the increase of enrolment rates have led the country to adopt the practice of double shift schooling at all levels. It must be noted that although the number varies from year to year, about 30 percent of school teachers at secondary level have been recruited from India (AfDB, 2004; UNECA, 2012).

\subsubsection{Meso and Micro-level Management Structures and Issues}

At regional level, the organizational structure of the Ministry of Education is comprised of sub-regional branches and five units at the regional headquarters. The units consist of basic education, secondary education, culture and sports, finance and administration and research, training and planning. The regional education branches are headed by directors, a post which is equivalent to division - level at the national headquarter office. According to the policy, regional education mangers are supposed to possess master's degree in education $(\mathrm{MoE}$, 2011). Historically, the appointment of posts has been made on the basis of commitment, loyalty to the system, and long- term service in the profession. In line with the decentralization policy, which was issued by the proclamation of Decree 86 in 1996, the regional education offices and schools are entitled to take decisions on various aspects that have to do with access, equity and quality of education (MoE, 2011, p. 3). The reality, 
however, is that the regional offices are strictly guided by the rules and regulations that originate from the Headquarter Office at a national level and the schools by the regional offices.

Currently, Eritrea has a three-band education system which consists of Basic Education (Pre School- grade eight), Secondary Education (grades nine-twelve) and Higher Education (MOE, 2011). Parallel to the formal education system, that runs from pre-school up to grade twelve (also known as general education system), there are various levels of Adult and Continuing Non-Formal Education and Technical and Vocational Education and Training, TVET, (MoE, 2009).

Basic Education comprises of pre-primary, elementary, and middle education for school-age children, and adult literacy and basic skill training for adults (MoE, 2011). For school age children, it refers to grades one to eight and is compulsory for all children until they reach the end of this cycle (MoE, 2009). The entire level accommodates school age children between the ages of six and thirteen. Pursuant to the National Curriculum Framework (MoE, 2009), the basic education level aims to lay a sound basis for further learning and growth and to produce morally, socially and civically responsible young citizens. Despite that intention, the basic education level in Eritrea has been characterized by high repetition rates, large number of children of dropouts, and low participation rates of girls (MoE, 2011; Rena, 2014).

Early Childhood or Pre-primary Education refers to community caregiver centers and pre-schools (kindergartens) which operate under the control and support of the regional offices of the Ministry of Education. Pre-school runs for two years and accommodates children up to the age of five (MoE, 2009). Preschools predominantly exist in urban areas, mainly in Asmara and are accessible only to limited portion of the population (MoE, 2011). The ownership, management, and source of financing of early childhood education is the responsibility of private institutions and communities (Gottesman, 2002). At a national level, however, schools and teachers are provided with functional support such as preserve and in-service trainings, monitoring of programs, and development of policies.

Elementary Education lasts five years and accommodates for school-age children from six to ten (MoE, 2009). Students begin officially at the age of six. However, in practice, delayed entry to school, that is up the age of eight, is not uncommon among the rural communities, especially in remote areas.

Middle Education (also known as junior or lower secondary education) lasts three years and refers to grade six to grade eight (MoE, 2009). Starting from elementary schools, all children are expected to continue until they reach middle school level with normal progression. Normally students join the middle education at age of eleven and finish at the age of thirteen in grade eight, which is the end of the basic education cycle in the Eritrean education system. All students who complete grade eight are required to sit for the National General Examination Certificate. Successful students (both from formal and non-formal education) are channeled to pursue their education at secondary level (MoE, 2011). In the past, those who could not manage to proceed further could repeat a grade (i.e. for one or two years only), but normally used to end up dropping out of the system. 
Secondary Education refers to grades nine to twelve. It consists of the last four years of the school system and accommodates students between the ages of fourteen through seventeen (MOE, 2011). Once students complete grade ten, depending on their performances, they have the option to divert from the academic stream to vocational education and training (MOE, 2013). Grade 12 is the final year of secondary school level.

The current arrangement requires all students in the country to complete their last year of education at a national boarding center known as "Warasy-Yikealo" Secondary School. As per the guideline of the National Curriculum Framework (MOE, 2009), at the end of grade twelve students are required to sit for Eritrean School Leaving Certificate Examination (ESLCE). Students who are successful in the ESLCE are eligible to join the institutions of higher learning at diploma and degree programs, while those who demonstrate poor performance are channeled to technical and vocational education and training (TVET).

As in other aspects, the current actual practices do not reflect the articulated policies on teacher qualification. Despite the claimed concerted efforts to reform the teacher education programs, the training programs at Asmara Teacher Education Institute have been incompatible with those provided by the College of Education at Eritrea Institute of Technology (EIT). According to a Concept Paper prepared to present a review of teacher preparation programs, the teacher education programs at both institutes have not been in tune with the reforms such as the inclusion of new subjects, the application of learner-centered and interactive pedagogy, and the introduction of new assessment practices which the ministry has been introducing into the system (MOE, 2012). The concept paper also noted that in both colleges, student teaches have not been adequately prepared for professional positions, and the outputs by both institutes have not been addressing the teacher demands in the country. The College of Education at EIT which is under the management of the National Board of Higher Education (NBHE) has been providing only six majors in diploma, and three in degree programs which do not reflect the reforms in the Ministry of Education. The Asmara Teacher Education Institute which is under the management of Ministry of Education has been suffering from acute shortage of qualified mother tongue educators and was limited to the provision of certificate programs for quite a long time. The overall organizational set-ups of teacher education schemes have not been rooted in such a way to vitalize the crucial role of teaching profession in the country.

The Eritrean Education system also consists of Adult and Continuing Non-Formal Education and Technical and Vocational Education and Training (TVET). These two sub-sectors are primarily aimed at providing education for coping with the requirements and demands of basic and medium level of occupational skills (MOE, 2011).

The Provision of Adult and Non-Formal Education in Eritrea consists of literacy and post-literacy programs which run for one and two years respectively (MOE, 2011). The programs accommodate primarily over-aged children (i.e. those within the ages of fifteen to forty-five), but also children aged nine to fifteen who for various reasons cannot join the conventional formal school system (MOE, 2009). They also open up an opportunity for the out-of-school children (dropouts and those who missed the opportunity to attend school) to 
benefit from the complementary education scheme which has been targeted for students aged nine to fourteen (MOE, 2009). The complementary education program puts special emphasis on girls.

The TVET Sub-sector provides basic, intermediate and junior level vocational education and training (MOE, 2011). The programs are aimed at producing semi-skilled manpower. As stipulated in the National Curriculum Framework (MOE, 2009), the durations of the training programs range between six months for the certificate training programs and three years for the diploma qualifications, and the contents vary accordingly.

Higher Education in Eritrea is public provision. It refers to the diploma and degree offering institutes of higher learning which constitute Eritrea Institute of Technology, College of Health Sciences, Orota School of Medicine, College of Business and Economics, College of Marine Sciences and Technology, Hamelmalo College of Agriculture and College of Arts and Social Sciences (Mehari, 2012). The University of Asmara, which was established by Italian missionaries in 1958, used to be the only higher education institute in the country until the end of 2003 (Mehari, 2012). More than 60 percent of instructors at institutes of higher learning are foreigners, mainly from India (UNECA, 2012).

\subsubsection{Language and Curriculum Issues}

Since independence, Eritrea has not proclaimed any official language. The constitution (i.e. Article 4) stated "The equality of all Eritrean languages is guaranteed" (GSE, 1997: 4). However, Tigrigna (also spelled as Tigrinya) and Arabic are officially known as working languages (Woldemikael, 2003). Of course, this seem to contradict with what is proclaimed by the policy. Both languages also serve as lingua-franca among the different ethno-linguistic groups in the country. In schools, the mother tongue (any of the nine Eritrean languages) is used as medium instruction, and English from middle school onwards (MoE, 2011). The mother tongue policy developed during the practices of the armed struggle has been implemented in the post-independence era as a medium of instruction at elementary level of schooling (MoE, 2009; Welde Giorgis, 2010). This policy was adopted not only from pedagogical point of view but also from a perspective that intends to symbolize the recognition given by the Eritrean government to cultural diversity and equality (MoE, 2011). As Arabic is one of the nine Eritrean languages, due to its historical importance to Eritrea, it is decided by the policy to be taught as a compulsory subject up to grade 12 in all schools (MoE, 2011). Nevertheless, the policy has not been materialized due to factors such as shortage of qualified teachers, lack of instructional materials, and policy shortcomings. The medium of instruction from middle school onwards is English, which is also taught as a subject up to higher education level.

\subsubsection{Gender and Geographical Inequalities}

This study contends that gender inequalities are among the key indicators of the overall disparities. Traditionally, Eritrean society was patriarchal, and both Muslim and Christian religions have been characterized by conservative norms and values (Smith, 2001; Stefanos, 1997). Such a culture contributed in perpetuating the stereotypes of women's contributions 
and abilities and also the traditional gender roles assigned to them by the Eritrean society. As noted by Sorenson $(1988$, p. 97) the traditional proverbs such as "just as there is no donkey with horns, so there are no women with brains" are indications of how women were looked down upon in the past. More recently, the Eritrean liberation struggle has transformed much of the values, prejudices and repressive practices that prevented women from playing active role in the society (Campbell, 2005; Sorenson, 1988). One notable change has been the empowerment of women in economic and political spheres. During the war for independence, women made up 15 percent of EPLF's military units and 35 percent in other services such as administrators, teachers, drivers, barefoot doctors, nurses, technicians, mechanics, and political cadres (GSE, 1993; Sorenson, 1998). In addition, there is disparity in the geographical distribution of schools. For instance, the number of secondary schools and students in the highlands is much higher than those in the lowland areas of Eritrea (Hailemariam, 2010; Rena, 2005). Almost all project and policy documents in the country do illustrate that there have been wide disparities and inequalities in access to schooling and to quality education in Eritrea. The disparities and inequalities seemed to exist in terms of location, gender, and socio-economic status. For instance, the participation of females has been low and the repetition and dropout rates as the major challenges of concern to the government and to parents.

\section{Conclusions and Future Research Direction}

The present study provides a good background information about Eritrea in general and its education system in particular. This study can be seen as adding to the literature on Eritrean education in that, it provides a discussion of Eritrean education at different period of time. This study reveals that the number of schools and student population has increased significantly after Eritrea's independence, although the Eritrean education system has faced formidable challenges. More importantly, this study can be useful and helpful for researchers who want to make education related studies in the Eritrean context. While this study is an important step forward in understanding Eritrean education system at different period of time, it also leaves some questions open for future research. This study is mainly based on in-depth-interviews with officials of the Eritrean Ministry of Education and analysis of published and unpublished documents. Hence, future research should be directed at examining Eritrean education system based on information collected from other stakeholders such as teachers, who are policy implementers, students, and their parents. Besides, future research should also be directed at assessing the impact of Eritrean economic and political situations on the Eritrean teachers' and students' quality, motivation, and turnover.

\section{References}

AfDB, OECD, UNDP, \& UNECA. (2012). African Economic Outlook Report 2012. Retrieved $\begin{array}{llll}\text { on } & \text { October } & 2018 & \text { from }\end{array}$ http://www.afdb.org/fileadmin/uploads/afdb/Documents/Publications/Eritrea\% 
20Full\%20PDF\%20Country\%20Note.pdf

African Development Bank (AfDB). (2004). Eritrea: Support to the Education Sector Development Program. Appraisal Report. Human and Social Development Department (OSHD), AfDB.

African Development Bank (AfDB). 2018 African Economic Outlook. Retrieved on October 9, 2018 from https://www.afdb.org/fileadmin/uploads/afdb/Documents/Generic-Documents/country_n otes/Eritrea_country_note.pdf

Al-Anazi, T. (2001). Strategic Importance of the Red Sea. Strategy Research Project. US Army War College, Carlisle Barracks, Pennsylvania. https://doi.org/10.21236/ADA394779

Bahta, Y. T., \& Haile, B. O. (2013). Determinants of Poverty of Zoba Maekel of Eritrea: A Household Level Analysis. International Journal of Food and Agricultural Economics (IJFAEC), 1(2), 73-84.

Bjorndal, I. K. M. (n.d.). If you don't do it our way, forget it! Contextualising Education in Eritrea: Reflections on a Research Experience. Retrieved on October 2, 2018 from http://www.netreed.uio.no/articles/Papers_final/bjorndal.pdf

Campbell, P. J. (2005). Gender and post-conflict civil society: Eritrea. International Feminist Journal of Politics, 7(3), 377-399. https://doi.org/10.1080/14616740500161110

CBS News (2018). Leaders of Ethiopia, Eritrea restore diplomatic relations after 20-year $\begin{array}{llll}\text { standoff. } & \text { Retrieved } & \text { Novemebr } & 1,\end{array}$ https://www.cbc.ca/news/world/ethiopia-eritrea-restore-diplomatic-relations-1.4738578

Collins, C. S., \& Wiseman, A. W. (2012). World Bang Group Education Strategy 2020 Learning for All: Investing in People's Knowledge and Skills to Promote Development. In Collins, C. S., \& Wiseman, A. W. (Eds.). Education strategy in the developing world: Revising the World Bank's education policy. Bingley: Emerald Books, International Perspectives on Education and Society, 16, 19-32.

Dutta, S., \& Choudhury, I. U. (2015). Status of household background characteristics and education. Paris: UNESCO.

Gottesman, L. (1998). To fight and learn. Lawrenceville, The Red Sea Press.

Gottesman, L. D. (2002). Eritrea. In Marlow-Ferguson, R., \& Lopez, C. (Eds.). World Education Encyclopedia: A Survey of Educational Systems Worldwide. Vol. 2. Gale Cengage, USA. 410-419.

Government of the State of Eritrea (GSE). (1994). Macro-Policy. Asmara, Eritrea.

Government of the State of Eritrea (GSE). (1997). The Constitution of Eritrea. Ratified by the Constituent Assembly, On May 23, 1997. Asmara, Eritrea.

Hailemariam, P. (2000). The Challenges of Educational Reconstruction and Transformation 
in Eritrea. In Teame, T., Michael, \& David, J. (Eds.), Globalisation, Educational Transformation and Societies in Transition. UK: Symposium Books, pp.127-136.

Hutchison, R. A., Spooner, B., \& Walsh, N. (Eds.). (1991). Fighting for survival: insecurity, people and the environment in the Horn of Africa. International Union for Conservation of Nature and Natural Resources (IUCN). Gland, Switzerland.

International Conference on Population and Development (ICPD) Beyond 2014. (2012). Eritrea Country Implementation Profile. Retrieved November 1, 2018 from http://icpdbeyond2014.org/documents/ download.php?f=FINAL_Eritrea.pdf

International Fund for Agricultural Development, (IFAD). (2009). Enabling the rural poor to overcome poverty in Eritrea. Retrieved October 2, 2018 from https://www.ifad.org/documents/10180/0c9b1957-8b85-4066-9be6-5ea0c1f78cd9

Iyob, R. (1997). The Eritrean Struggle for Independence: domination, resistance, nationalism, 1941-1993. Cambridge University Press, 82.

Kidane, E. (2004). A Brief Historical Account of Formal Education in Eritrea. Retrieved October 29, 2018 from http://www.ehrea.org/kidaneed.htm

Madote.com. (2013). Why is Eritrea's Economic Boom Being Ignored by the IMF? Retrieved $\begin{array}{llll}\text { October 22, } & 2018 \text { from }\end{array}$ http://www.madote.com/2013/12/why-is-eritreas-economic-boom-being.html

Mehari, T. (2012). Higher Education in Eritrea. Seminar Paper by Executive Director of the National Board for Higher Education in Eritrea (NBHE). Asmara, NBHE.

Ministry of Education (MOE), the State of Eritrea. (2001). Our People are Our Future: A Framework for the Development of Human Resources in the Education Sector. Asmara, Ministry of Education.

Ministry of Education (MOE), the State of Eritrea. (2009). The National Curriculum Framework: Eritrea. Asmara, Ministry of Education.

Ministry of Education (MOE), the State of Eritrea. (2011). National Education Policy. Asmara, Ministry of Education.

Ministry of Education (MOE), the State of Eritrea. (2013). Education Sector Development Plan - 2013 - 2017. Asmara, Ministry of Education.

Ministry of Education. (2012). Eritrea: Essential Indicators, 2011/12. Asmara, Ministry of Education.

Ministry of Land, Water \& Environment (MLWE), the State of Eritrea. (2001). Eritrea's Initial National Communication. Under the United Nations Framework Convention on Climate Change (UNFCCC). Asmara, Ministry of Land, Water \& Environment Ministry of Education (MOE), the State of Eritrea. (2003). Eritrea: National Education Policy. Asmara, Ministry of Education. 
Ministry of Land, Water \& Environment (MLWE), the State of Eritrea. (2007). National Adaptation Program of Action. Asmara, Ministry of Land, Water \& Environment.

Pateman, R. (1998). Eritrea: even the stones are burning. The Red Sea Press, New Jersey, USA.

Pool, D. (1997). Eritrea Towards Unity in Diversity (Minority Rights Group International Report). London: Minority Rights Group.

Rena, P. (2005). Eritrean Education: Retrospect and Prospect. East Africa Journal of Humanities and Sciences, 5(2), 1-12.

Rena, R. (2014). Eritrea: Educational Development Pre- and Post-Independence. In Wolhuter, C. (Ed.), Education in East and Central Africa (pp. 191-222). London, New Delhi: Bloomsbury.

Schraeder, P. J. (1992). The Horn of Africa: US foreign policy in an altered Cold War environment. The Middle East Journal, 46(4), 571-593.

Schwab, P. (1978). Cold War on the Horn of Africa. African Affairs, 77(306), 6-20. https://doi.org/10.1093/oxfordjournals.afraf.a096955

Smith, C. M. (2001). Women and Education in Eritrea: Society and Development. Retrieved October 12, 2018 from http://rri.wvu.edu/wp-content/uploads/2012/12/REU2001-22.pdf

Sorenson, J. (1988). Eritrean Women: Dual Struggle in the Horn of Africa. Canadian Woman Studies, 9(3).

Stacey, N. (1998). Social benefits of education. The Annals of the American Academy of Political and Social Science, 559(1), 54-63.

State University.com (2014). Eritrea - History \& Background. Education Encyclopedia, Global Education Reference. Retrieved October 27, 2018 from http://education.stateuniversity.com/pages/434/Eritrea-HISTORY-BACKGROUND.htm 1

Stefanos, A. (1997). Women and education in Eritrea: A historical and contemporary analysis. Harvard Educational Review, 67(4), 658-689. https://doi.org/10.17763/haer.67.4.2821602nw5445414

Tesfagiorgis, M. G. (2010). Eritrea. ABC-CLIO, Santa Barbara, California, USA.

The Japan Times, Monday, May 18, 2009, 5. Eritrea entering a new phase. Retrieved from October 8 , 2018 http://info.japantimes.co.jp/international-reports/pdf/20090518-panorama-eritrea.pdf

Thompson, S. (2014). Encyclopedia of Diversity and Social Justice. Lanham, Maryland; London: Rowman \& Littlefield.

Tronvoll, K. (1998). The process of nation-building in post-war Eritrea: created from below or directed from above? The Journal of Modern African Studies, 36(3), 461-482. 
https://doi.org/10.1017/S0022278X98002833

UNESCO (2015). World Education Forum 2015: Final Report. Paris: UNESCO.

UNESCO (2011). Global Monitoring Report 2011: The hidden crisis: Armed conflict and education. Paris: UNESCO.

UNDP (2013). World Population Prospects: The 2012 Revision. Department of Economic and Social Affairs, Population Division. Retrieved October 9, 2018 from http://esa.un.org/wpp/Documentation/pdf/WPP2012_\% 20KEY\%20 FINDINGS.pdf

UNDP (2017). Human Development Report. Retrieved November 1, 2018 from http://hdr.undp.org/en/composite/HDI

Welde Giogis, A. (2010). Nation Building, State Construction and Development in Africa: The Case of Eritrea. Retrieved October 6, 2018 from http://library.fes.de/pdf-files/iez/08268.pdf

Weldeyesus, W. (2009). Eritrea: History and Culture. Retrieved October 27, 2018 from http://www.shabait.com/about-eritrea/history-a-culture/450-italian-administration-in-erit rea

White, P. (2005). War and food security in Eritrea and Ethiopia, 1998-2000. Disasters, 29(1), 2-113. https://doi.org/10.1111/j.0361-3666.2005.00286.x

Woldemikael, T. M. (2003). Language, education, and public policy in Eritrea. African Studies Review, 46(1), 117-136. https://doi.org/10.2307/1514983

World Bank (2013). Africa Development Indicators: 2012/13. International Bank for Reconstruction and Development. Retrieved October 6, 2018 from https://openknowledge.worldbank.org/bitstream/handle/10986/13504/9780821396162.p df? sequence $=1$

World Bank (2014). Eritrea Overview. Retrieved November 1, 2018 from http://www.worldbank.org/en/ country /eritrea/overview\#1

WHO (2010). Eritrea Factsheets of Health Statistics 2010. Retrieved October 24, 2018 from http://www.ecoi.net/file_upload/1788_1322492169_eritrea-statistical-factsheet.pdf

WHO (2016). Life expectancy in Eritrea. Retrieved October 19, 2018 from http://www.who.int/countries/eri/en/

\section{Copyright Disclaimer}

Copyright for this article is retained by the author(s), with first publication rights granted to the journal.

This is an open-access article distributed under the terms and conditions of the Creative Commons Attribution license (http://creativecommons.org/licenses/by/3.0/). 